\title{
Evaluation of ph stability, concentration and antimicrobial activity in commercial
}

\section{brands of sodium hypochlorite solution}

\author{
Avaliação da estabilidade do ph, concentração e atividade antimicrobiana em marcas comerciais da \\ solução de hipoclorito de sódio
}

Evaluación de la estabilidad del ph, la concentración y la actividad antimicrobiana en marcas comerciales de solución de hipoclorito de sodio

Received: 03/08/2021 | Reviewed: 03/16/2021 | Accept: 03/18/2021 | Published: 03/28/2021

Bianca Maria Beserra Costa

ORCID: https://orcid.org/0000-0002-8132-9881

Universidade de Pernambuco, Brazil

E-mail: bianca.bcosta@upe.br

Maria Katharina Peixoto da Silva

ORCID: https://orcid.org/0000-0002-0652-8805

Faculdade de Odontologia do Recife, Brazil

E-mail: katharinapeixoto@ hotmail.com

Sandra Maria Alves Sayão Maia

ORCID: https://orcid.org/0000-0003-3172-2332

Universidade de Pernambuco, Brazil

E-mail: sandrinhasayao@hotmail.com

Paulo Maurício Reis de Melo Júnior

ORCID: https://orcid.org/0000-0001-9926-5348

Universidade de Pernambuco, Brasil E-mail: Paulo.reis@upe.br

Natália Gomes de Oliveira

ORCID: https://orcid.org/0000-0001-6937-1537

Universidade de Pernambuco, Brazil

E-mail: nataliagomes04@hotmail.com

Luís Felipe Espíndola Castro

ORCID: https://orcid.org/0000-0002-1923-8057

Universidade de Pernambuco, Brazil

E-mail: lipe_espindola@hotmail.com

Pâmella Recco Álvares

ORCID: https://orcid.org/0000-0003-3396-9339 Universidade de Pernambuco, Brazil

E-mail: pamella.recco@upe.br

Jorge Miguel Albrecht Ribeiro Filho

ORCID: https://orcid.org/0000-0002-3772-1851

Faculdade de Odontologia do recife, Brazil

E-mail: Jorge_albrechtfilho@hotmail.com

\begin{abstract}
The present work refers to an in vitro study of different commercial brands of sodium hypochlorite (manipulated, Soda Chlorine and Brilux) being evaluated by means of $\mathrm{pH}$, antimicrobial action and concentration, at time intervals of 0,7 and 14 days, in a refrigerated environment and at room temperature, and with receiving and absence of light. The antimicrobial assay of the solutions was performed by the disk diffusion method. Enterococcus faecalis was grown on Tryptic Soil Agar (TSA) (Merk) and incubated at $\pm 35^{\circ} \mathrm{C}$ for 24 hours. The active chlorine content was verified by iodometric titration, and the $\mathrm{pH}$, by $\mathrm{pH}$ measuring tape. The results suggest that there was no statistically significant relevance in the results of the active chlorine content. The $\mathrm{pH}$ became higher with time, and the antimicrobial activity was altered according to the storage location and time.
\end{abstract}

Keywords: Sodium hypochlorite; Endodontics; Enterococcus faecalis.

\section{Resumo}

$\mathrm{O}$ presente trabalho refere-se a uma pesquisa in vitro de diferentes marcas comerciais de hipoclorito de sódio (manipulada, Soda Clorada e Brilux) sendo avaliados mediante ao $\mathrm{pH}$, ação antimicrobiana e concentração, em intervalos de tempos de 0, 7 e 14 dias, em ambiente refrigerado e na temperatura ambiente, e com recebimento e ausência de luz. O ensaio antimicrobiano das soluções foi realizado pelo método de difusão em disco. O Enterococcus faecalis foi cultivado em Tryptic Soil Agar (TSA) (Merk) e incubado a $\pm 35^{\circ} \mathrm{C}$ por 24 horas. O teor de cloro ativo foi 
verificado através da titulação iodométrica, e o pH, através da fita medidora de $\mathrm{pH}$. Os resultados sugerem que não houve relevância estatisticamente significante nos resultados do teor de cloro ativo. $\mathrm{O}$ pH se tornou mais elevado a medida do tempo, e a atividade antimicrobiana foi alterada de acordo com o local de armazenamento e o tempo.

Palavras-chave: Hipoclorito de Sódio; Endodontia; Enterococcus faecalis.

\section{Resumen}

El presente trabajo se refiere a una investigación in vitro de diferentes marcas comerciales de hipoclorito de sodio (manipulado, Soda Chlorine y Brilux) siendo evaluado por medio del pH, la acción antimicrobiana y la concentración, en intervalos de tiempo de 0, 7 y 14 días, en un ambiente refrigerado y a temperatura ambiente, y con recepción y ausencia de luz. El ensayo antimicrobiano de las soluciones se realizó por el método de difusión en disco. Enterococcus faecalis se cultivó en Agar Tríptico para Suelos (TSA) (Merk) y se incubó a $\pm 35^{\circ} \mathrm{C}$ durante 24 horas. El contenido de cloro activo se verificó mediante titulación yodométrica, y el pH, mediante cinta métrica de $\mathrm{pH}$. Los resultados sugieren que no hubo una relevancia estadísticamente significativa en los resultados del contenido de cloro activo. El pH aumentó con el tiempo, y la actividad antimicrobiana se alteró según el lugar y el tiempo de almacenamiento.

Palabras clave: Hipoclorito de sodio; Endodoncia; Enterococcus faecalis.

\section{Introduction}

The main goal of endodontic treatment is to achieve the disinfection of the entire root canal system, which presupposes the elimination of microorganisms, while also preventing the recurrence of infection during and after treatment. This goal is only achieved through the use of mechanical canal instrumentation systems, associated with the correct use of irrigation solutions (Plotino et al., 2016).

Studies show that up to $79 \%$ of the surface area of ducts remains untouched, regardless of the system used (Versiani et al., 2015; Lopes et al., 2018). This deficiency in cleaning makes mechanical removal of biofilm even in canals with less complex anatomy. Thus, in order to have an effective protocol for removing the bacterial biofilm the activation of irrigating solutions inside the root canal system is necessary to obtain root canal system, in order to obtain a greater dispersion in regions not reached during instrumentation not reached during instrumentation, penetrating the ramifications and isthms. (Lin, Shen, \& Haapasalo, 2013; Dioguardi et al., 2018)

Among the various irrigation solutions used in endodontics, sodium hypochlorite has always occupied an important position, since its origin until today. Its first presentation was in 1792, produced by the French chemist Berthollet (Neris, Arruda, Duque, Neris, \& Galindo, 2015).

Sodium hypochlorite $(\mathrm{NaOCl})$ is the irrigant of choice for endodontists, due to its efficiency against various species of microorganisms. In addition, it has low cytotoxicity and is capable of dissolving necrotic tissue. Chlorhexidine (CHX), unlike $\mathrm{NaOCl}$, does not have this tissue dissolving property. Therefore, it is used only when the intent is for antimicrobial action (YOO et al., 2019). Sodium hypochlorite ( $\mathrm{NaOCl}$ ) is a halogenated compound and was first employed in dentistry, adopted by the name of Javale's Water, composed of sodium and potassium hypochlorite, through the electrolysis of a sodium chloride solution that is available in the form of aqueous solution, a condition that gives rise to sodium hydroxide and hypochlorous acid. (Paixão \& Maltos, 2016).

Among the main indications of sodium hypochlorite is the ability to partially neutralize toxic products, decreasing the viability of bacteria dissemination in the apical region; the bactericidal power, through the release of oxygen and chlorine; the alkaline $\mathrm{pH}$, canceling the acidity and making the medium inappropriate for bacterial growth; the solvent action of the pulp tissue; ability to dehydrate and solubilize protein substances and the detergent action, acting on fatty acids, saponifying them and facilitating the action of instruments. (Ferreira, 2016).

However, the instability in the concentration of hypochlorite is well known, due to improper storage that leads to loss of active chlorine content, limiting its concentration in relation to its initial state. With this, over time it is not possible for the 
operator to guarantee the concentration that is being used, often during the procedure. In many cases with its storage in an erroneous way, a solution with low antimicrobial function and low tissue dissolution is employed (Neris et al., 2015).

The chemical instability of chlorine in solutions is due to several factors, such as temperature, storage, luminosity and the hydrogen potential $(\mathrm{pH})$ that can influence the rapid loss of active chlorine content, making it possible for professionals to be unaware of the true concentration of the solution at the time of its use (Ludwig et al. 2007; Borin \& Oliveira, 2008; Avila, Santos, Siqueira, Nicoletti \& Bombana, 2010; Romulu, Brito, Machado \& Nabeshima, 2015).

Therefore, the aim of this work is to analyze in vitro the stability of $\mathrm{pH}$, antimicrobial activity and concentration of sodium hypochlorite solution, simulating the interference of the clinical environment in different storage sites, different commercial brands, at different time intervals.

\section{Methodology}

This was a quantitative and experimental study (Pereira, Shitsuka, Parreira, \& Shitsuka, 2018). That was conducted at ECAP Microbiological Laboratory in the period from December 2017 to October 2018. The sample was composed of sodium hypochlorite-based chemical solutions sold in supermarkets, dental supply stores, and compounding pharmacies. Inclusion criteria for the study were newly manufactured or manipulated $2.5 \%$ sodium hypochlorite-based substances. The storage of the solutions was chosen in order to simulate a dental office. The solutions were divided into four environments: refrigerated, refrigerated with light, room temperature, and room temperature with light. Where temperature and luminosity were controlled and checked.

The analysis of the chlorine content in the solutions was performed at the tested time intervals by means of the indirect oxireduction titration method or iodometry, described in the British Pharmacopoeia. $10 \mathrm{~mL}$ of the sample was pipetted into a $50 \mathrm{~mL}$ volumetric flask. The volume was made up with distilled water and homogenized. From this solution, $10 \mathrm{~mL}$ was transferred to the capped Erlenmeyer flask containing $2 \mathrm{~g}$ of potassium iodide and weighed on an analytical balance. $10 \mathrm{~mL}$ of acetic acid $(6 \mathrm{~N})$ was added to the Erlenmeyer flask containing potassium iodide and homogenization was carried out. Transfer $10 \mathrm{~mL}$ of the solution from the volumetric flask to the Erlenmeyer flask to release the iodine. The released iodine was titrated under stirring with sodium thiosulfate $0.1 \mathrm{~N}$ until the solution became colorless. Each mL of sodium thiosulfate $0.1 \mathrm{~N}$ is equivalent to $3.722 \mathrm{mg}$ of sodium hypochlorite. For greater reliability of the results, triplicate analyses were performed. The result is the simple arithmetic mean of the three values expressed as percentages of chlorine remaining in the $2.5 \%$ sodium hypochlorite solutions.

The $\mathrm{pH}$ of the samples at room temperature was measured with a $\mathrm{pH}$ measuring tape (Machery-Nagel $\mathrm{pH}-$ fix 0-14). The $\mathrm{pH}$ measurements were performed by submerging the tape in $2 \mathrm{ml}$ of each solution contained in a plastic container at all time intervals and the $\mathrm{pH}$ value and temperature were recorded at the time of reading. After each measurement the samples (2 $\mathrm{ml}$ ) were discarded.

Bacterial strain of Enterococcus faecalis was used in the microbial sensitivity assay. The strain originated from the bacterioteca of the Department of Antibiotics of the Federal University of Pernambuco ATCC. The bacterial strain was maintained at $\pm 5^{\circ} \mathrm{C}$ in Tryptic Soil Agar (TSA) culture medium (Merk).

The antimicrobial assay of the solutions was performed by the disk diffusion method (Bauer et al., 1966). The bacteria were grown on Tryptic Soil Agar (TSA) (Merk) and incubated at $\pm 35^{\circ} \mathrm{C}$ for 24 hours. The bacterial inoculum was prepared by direct suspension in saline solution (0.9\%). The suspension was adjusted using McFarland's 0.5 standard scale with $1.5 \times 108$ CFU/mL. From the adjusted suspension, $0.1 \mathrm{~mL}$ was seeded, with a sterile Dirgalski loop, onto Tryptic Soil Agar (TSA) (Merk) contained in a Petri dish (90 $\mathrm{mm}$ diameter). Three $6 \mathrm{~mm}$ diameter $\varnothing 125 \mathrm{~mm}$ filter paper disks (Unifil C40) were placed 
equidistant on the TSA surface, and the applications of these were performed with the aid of sterile forceps to avoid contamination.

The plates were then incubated in an incubator at $\pm 35{ }^{\circ} \mathrm{C}$ for 24 hours. After the incubation period, the diameter of the inhibition halos of bacterial growth was read, including the diameter of the disc using a pachymeter, and the data were represented by the average of the two assays (tests in duplicates).

The data obtained regarding ph values, microbial inhibition halos and free chlorine concentration were tabulated and analyzed descriptively by means of mean and standard deviation (mean \pm SD). To evaluate the difference between the evaluation times ( 0 days, 7 days and 14 days), between hypochlorites 1 (Manipulated), 2 (Chlorinated Soda Asfer) and 3 (Brilux) or between the conditions (ambient temperature with light, ambient temperature without light, refrigerated environment with light, and refrigerated environment without light) the Kruskal-Walis test was used, and in case of significant difference, multiple comparisons of this test were used. In the comparison between the conditions: light and dark of each type (counter or refrigerator) the Mann-Whitney test was used. The choice of the non-parametric Kruskal-Wallis and MannWhitney tests was due to the number of observations in each combination of condition, type of hypochlorite and evaluation time (maximum of 6 , which is insufficient to verify the normality hypothesis).

The margin of error used in the decision of the statistical tests was 5\%. The data were entered into the EXCEL spreadsheet and the program used to obtain the statistical calculations was IBM SPSS version 23.

The research was developed in a laboratory environment and in accordance with the resolution number 466/2012 of the National Health Council, and the declaration of Helsinki VI, promulgated in 2000, regarding ethics in research involving human subjects. The project is exempted by the ethics and research committee for consideration and opinion because it is an "in vitro" study.

\section{Results}

The $\mathrm{pH}$ values of the sodium hypochlorite solutions in the different storage locations and time intervals tested are shown in charts $1,2,3$, and 4 .

Graph 1 - pH values of the chemical solutions at room temperature with light.

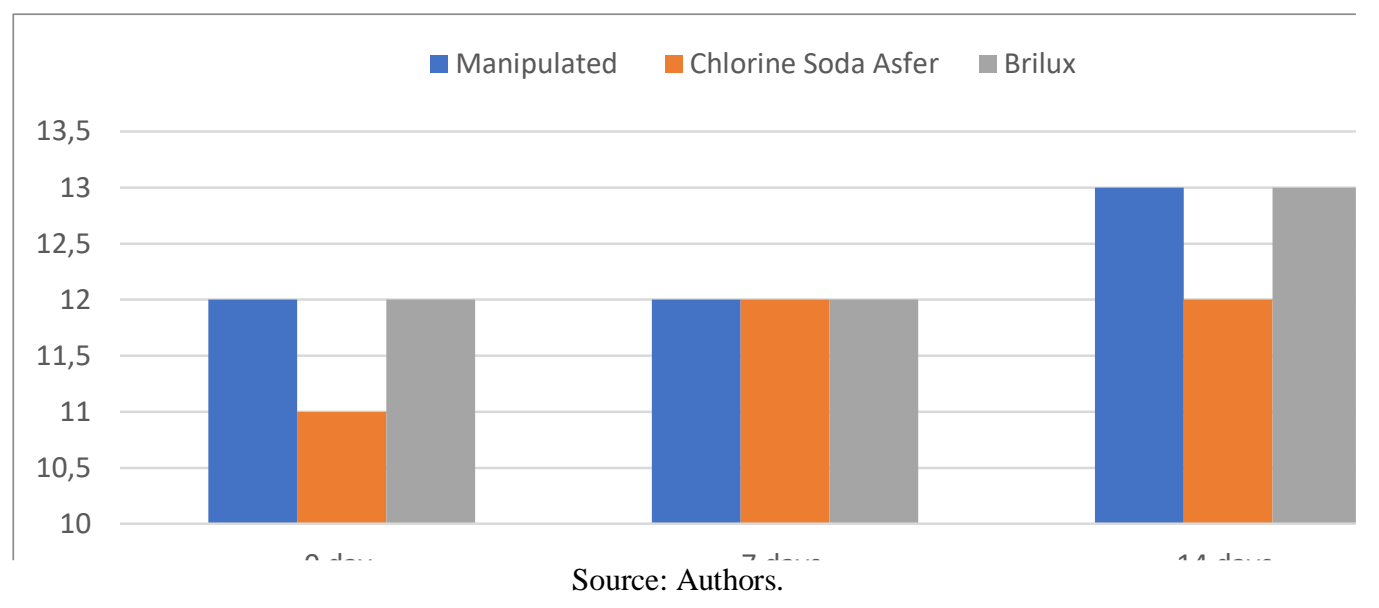


Research, Society and Development, v. 10, n. 3, e54910313658, 2021

(CC BY 4.0) | ISSN 2525-3409 | DOI: http://dx.doi.org/10.33448/rsd-v10i3.13658

Graph 2 - pH values of chemical solutions at room temperature, without luminosity.

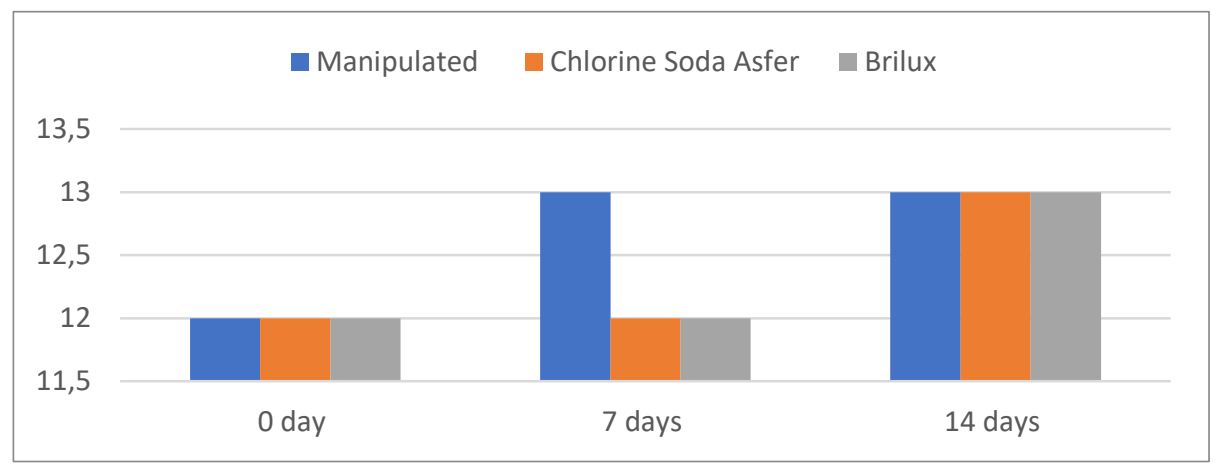

Source: Authors.

Graph 3 - pH values of chemical solutions in a refrigerated environment, with luminosity.

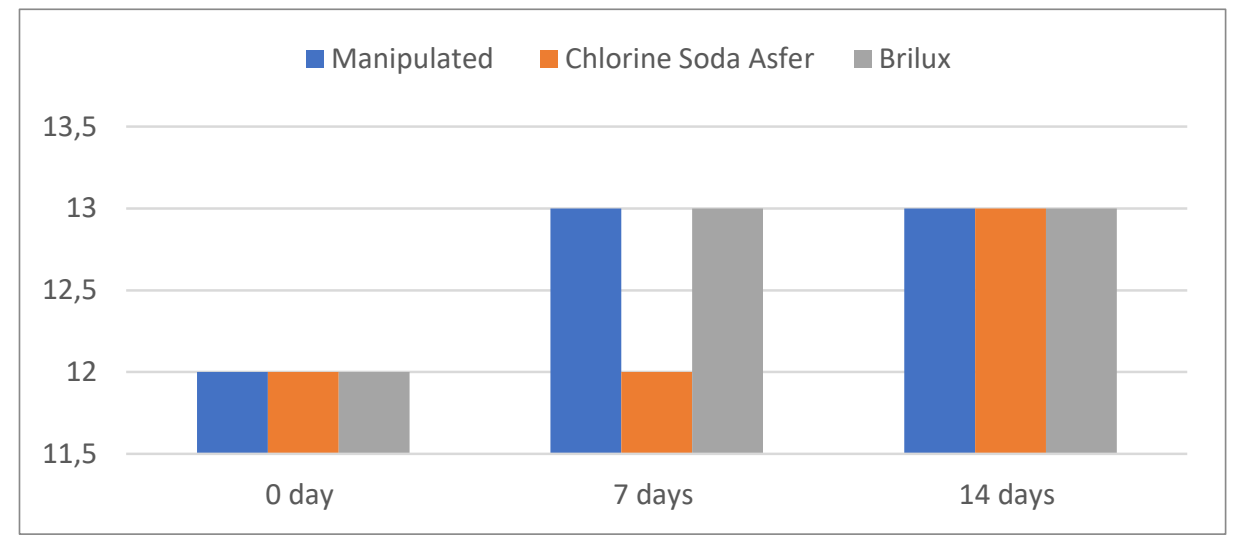

Source: Authors.

Graph 4 - pH values of chemical solutions in a refrigerated environment, without luminosity.

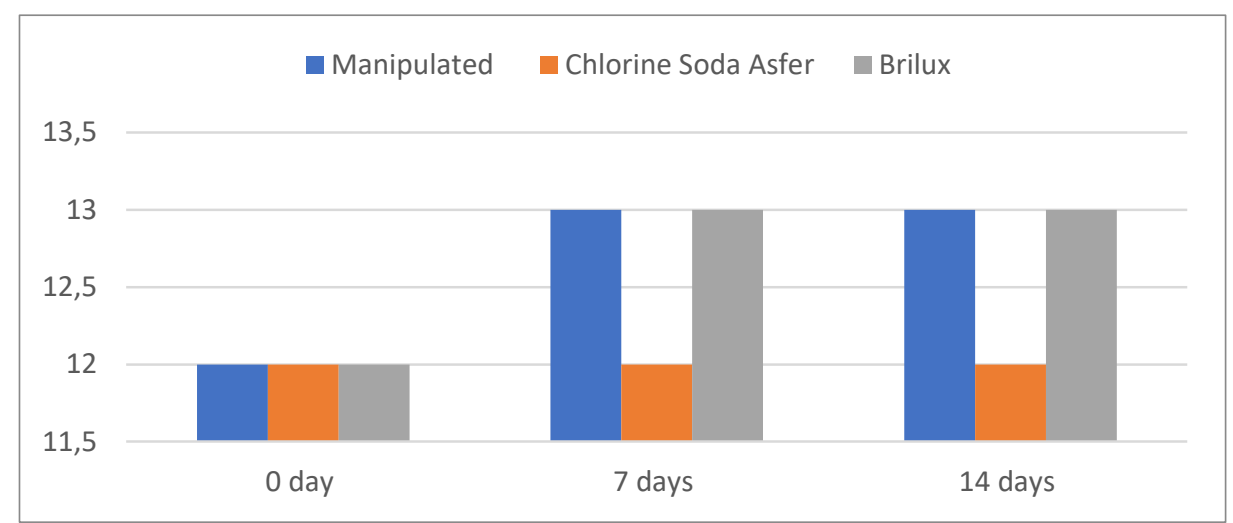

Source: Authors. 
With the exception of the results of the samples from solution 2 (chlorinated soda - counter/dark), which presented the same values at "0 days" and "14 days", and solution 1 (manipulated - refrigerator/dark) with the lowest mean at "0 days", in the other situations, the lowest means were at "14 days" (Table 1).

In the light refrigerator the averages were correspondingly higher at 0 days in all three sodium hypochlorite solutions and in the dark refrigerator they were highest at 7 days. With the exception of dark counter in hypochlorite 3 in the other situations significant differences $(\mathrm{p}<0.05)$ were recorded between the evaluation times for the fixed margin of error $(5 \%)$; for the samples with significant differences the tests of multiple comparisons showed significant differences between 14 days of the other two evaluations in the samples of light counter and dark counter, hypochlorite 1 of the light refrigerator and hypochlorite 2 of the dark refrigerator; between the three evaluation times for hypochlorites 2 and 3 in the light refrigerator and hypochlorite 3 (Brilux) in the dark refrigerator; between 7 days with each of the other evaluation times for hypochlorite 1 in the dark refrigerator.

Significant differences between the hypochlorites were recorded in the evaluations at 14 days in the light counter and dark counter, light refrigerator at 7 days and dark refrigerator at 0 days, with a significant difference between hypochlorite 3 and the other two hypochlorites in the light counter, between hypochlorite 1 and the other two in the dark refrigerator, between hypochlorites 2 and 3 in the light refrigerator, and between hypochlorite 2 and the other two hypochlorites in the dark refrigerator; least high in hypochlorite 1 and highest in hypochlorite 3 in the dark refrigerator; least high in hypochlorite 2 in the light refrigerator and highest in hypochlorite 2 in the dark refrigerator. As can be seen in Graphs 5, 6, 7, 8 and 9.

The variability expressed by the standard deviation was reduced since these measurements were less than $1 / 3$ of the corresponding means. 
Table 1 - Mean and standard deviation of antimicrobial activity ( 2.1 x 108 cells inoculated at each time) according to condition, type of hypochlorite and evaluation time.

\section{Time in days}

\begin{tabular}{|c|c|c|c|c|c|}
\hline \multirow[t]{2}{*}{ Condition } & \multirow[t]{2}{*}{$\begin{array}{l}\text { Hypochlorite } \\
\text { type }\end{array}$} & Day 0 & Day 7 & Day 14 & \multirow[t]{2}{*}{ Value of $p$} \\
\hline & & Average $\pm S D$ & Average \pm SD & Average $\pm S D$ & \\
\hline
\end{tabular}

\section{Ambient}

Temperature

2

with luminosity

$2,08 \pm 0,34^{(\mathbf{A})} \quad 1,87 \pm 0,20^{(\mathbf{A})} \quad 1,52 \pm 0,30^{(\mathbf{B}, \mathbf{a})} \quad \mathrm{p}^{(1)}=0,013^{*}$

3

$1,82 \pm 0,20^{(\mathbf{A})} \quad 1,97 \pm 0,14^{(\mathbf{A})} \quad 1,22 \pm 0,17^{(\mathbf{B}, \mathbf{b})} \quad \mathrm{p}^{(1)}=0,002^{*}$

Value of $p$

$p^{(2)}=0,113 \quad p^{(2)}=0,644 \quad p^{(2)}=0,032 *$

1

$1,66 \pm 0,24^{(\mathbf{A})}$

$1,82 \pm 0,17^{(\mathbf{A})}$

$1,22 \pm 0,12^{(\mathbf{B}, \mathbf{a})} \quad \mathrm{p}^{(1)}=0,003^{*}$

Ambient

Temperature

Without Lighting

2

$1,45 \pm 0,19^{(\mathbf{A})} \quad 1,80 \pm 0,18^{(\mathbf{A})}$

$1,45 \pm 0,10^{(\mathbf{B}, \mathbf{b})} \quad \mathrm{p}^{(1)}=0,010^{*}$

3

$1,70 \pm 0,19 \quad 1,70 \pm 0,30$

$1,50 \pm 0,15^{(\mathbf{b})} \quad \mathrm{p}^{(1)}=0,429$

Value of $p$

$\mathbf{p}^{(2)}=0,067 \quad \mathbf{p}^{(2)}=0,790 \quad \mathbf{p}^{(2)}=0,012 *$

1

$1,97 \pm 0,16^{(\mathrm{A})}$

$1,90 \pm 0,13^{(\mathbf{A}, \mathbf{a b})}$

$1,22 \pm 0,10^{(\mathbf{B})}$

$\mathrm{p}^{(1)}=0,002^{*}$

Temperature

Cooled with

luminosity

2

$2,00 \pm 0,30^{(\mathbf{A})}$

$1,77 \pm 0,15^{(\mathbf{B}, \mathbf{a})}$

$1,35 \pm 0,14^{(\mathbf{C})}$

$\mathrm{p}^{(1)}=0,003^{*}$

3

$2,27 \pm 0,21^{(\mathbf{A})}$

$1,97 \pm 0,05^{(\mathbf{B}, \mathbf{b})}$

$1,32 \pm 0,23^{(\mathrm{C})} \quad \mathrm{p}^{(1)}=0,002^{*}$

Value of $p$

$\mathbf{p}^{(2)}=0,162$

$\mathbf{p}^{(2)}=0,029^{*} \quad \mathbf{p}^{(2)}=0,255$

1

$1,43 \pm 0,27^{(\mathbf{A}, \mathbf{a})}$

$2,12 \pm 0,25^{(\mathbf{B})}$

$1,48 \pm 0,33^{(\mathbf{A})}$

$\mathrm{p}^{(1)}=0,005^{*}$

Cooled

Temperature

without

luminosity

2

$2,00 \pm 0,19^{(\mathbf{A}, \mathbf{b})} \quad 2,02 \pm 0,36^{(\mathbf{A})}$

$1,30 \pm 0,09^{(\mathbf{B})} \quad \mathrm{p}^{(1)}=0,003^{*}$

3

$1,53 \pm 0,08^{(\mathbf{A}, \mathbf{a})} \quad 2,02 \pm 0,04^{(\mathbf{B})}$

$1,38 \pm 0,12^{(\mathrm{C})} \quad \mathrm{p}^{(1)}=0,001^{*}$

Value of $p$

$\mathbf{p}^{(2)}=0,004^{*}$

$\mathbf{p}^{(2)}=\mathbf{0 , 5 5 6}$

$\mathbf{p}^{(2)}=0,606$

(*) Significant difference at 5\%.

(1) Using the Kruskal Wallis test for comparison between the evaluation times in each condition and type of hypochlorite with multiple comparisons of the test itself 
(2) Using the Kruskal Wallis test for comparison between the types of hypochlorite per condition and evaluation time in each condition and type of hypochlorite with multiple comparisons of the test itself

Note: If all capital letters in parentheses are distinct, significant differences between the corresponding times are verified.

Note: If all lower case letters in parentheses are distinct, significant differences between the corresponding hypochlorite types are proven.

Sources: Authors

Graph 5 - Mean and standard deviation of antimicrobial activity (2.1 x 108 cells inoculated at each time) according to condition, type of hypochlorite, and evaluation time.

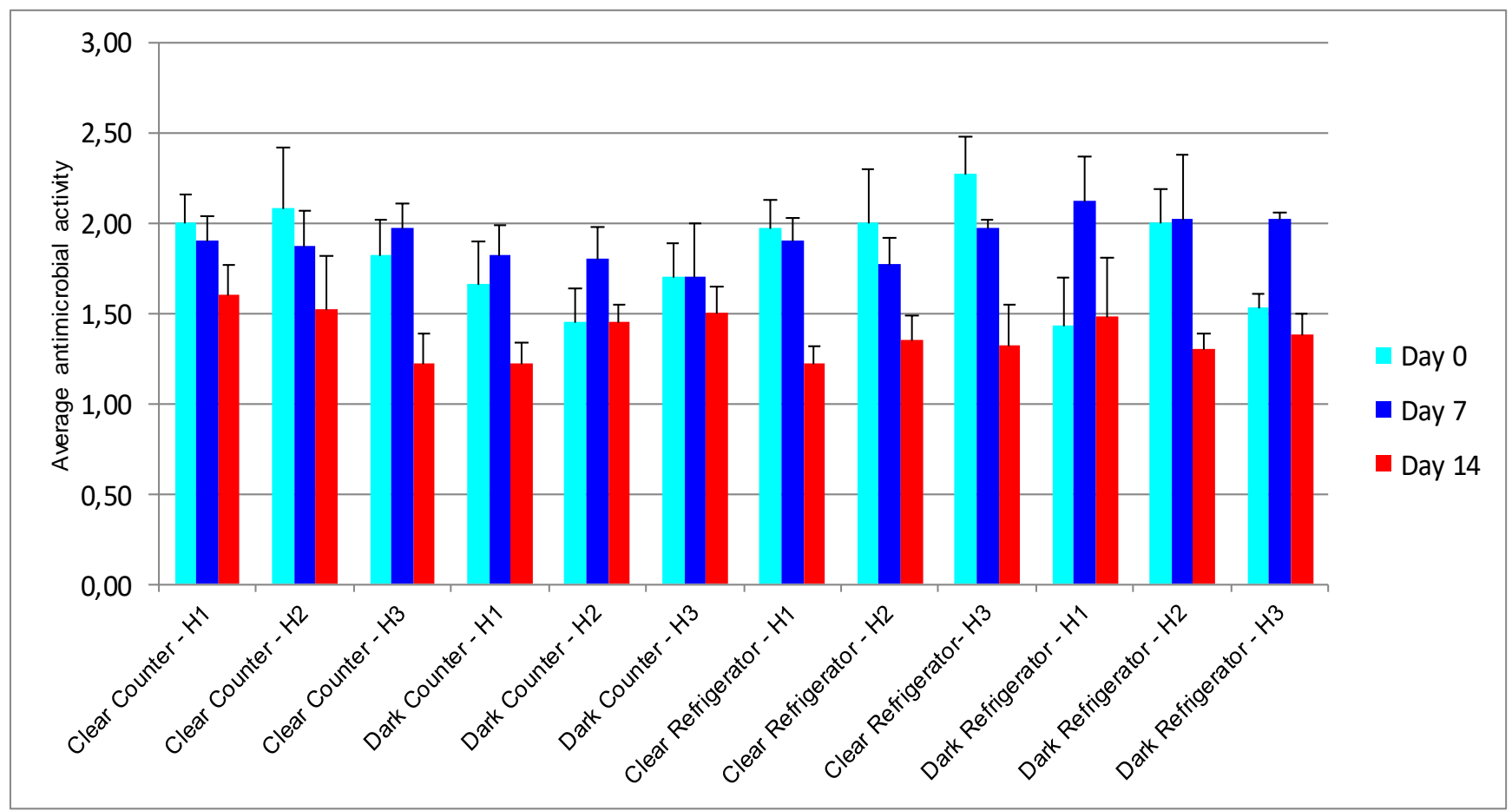

Source: Authors.

Graph 6 - Mean and standard deviation of antimicrobial activity (2.1 x 108 cells inoculated at each time) according to the type of hypochlorite and evaluation time in the clear counter condition.

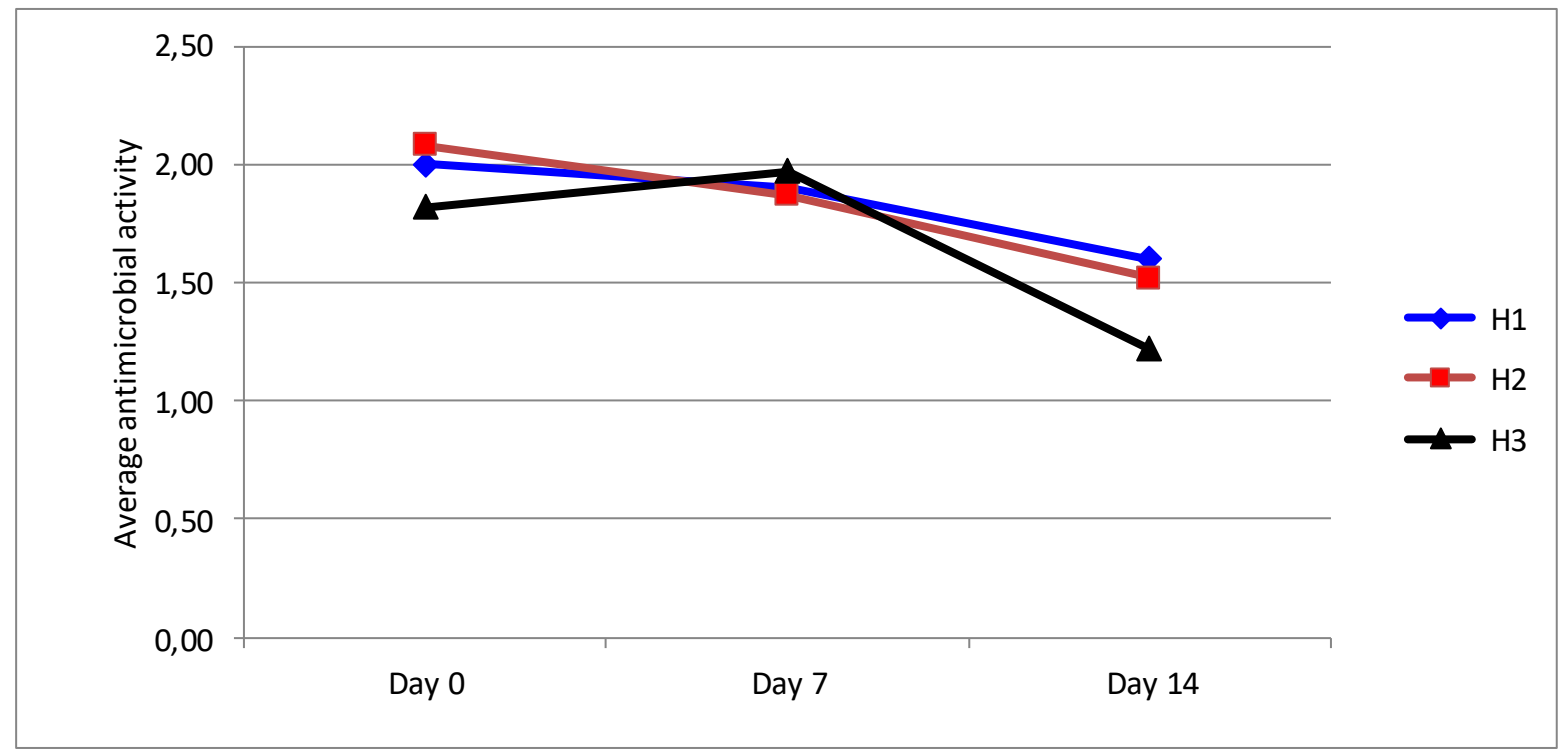

Source: Authors. 
Research, Society and Development, v. 10, n. 3, e54910313658, 2021

(CC BY 4.0) | ISSN 2525-3409 | DOI: http://dx.doi.org/10.33448/rsd-v10i3.13658

Graph 7 - Mean and standard deviation of antimicrobial activity x (2.1 x 108 cells inoculated at each time) according to the type of hypochlorite and evaluation time in the dark counter condition.

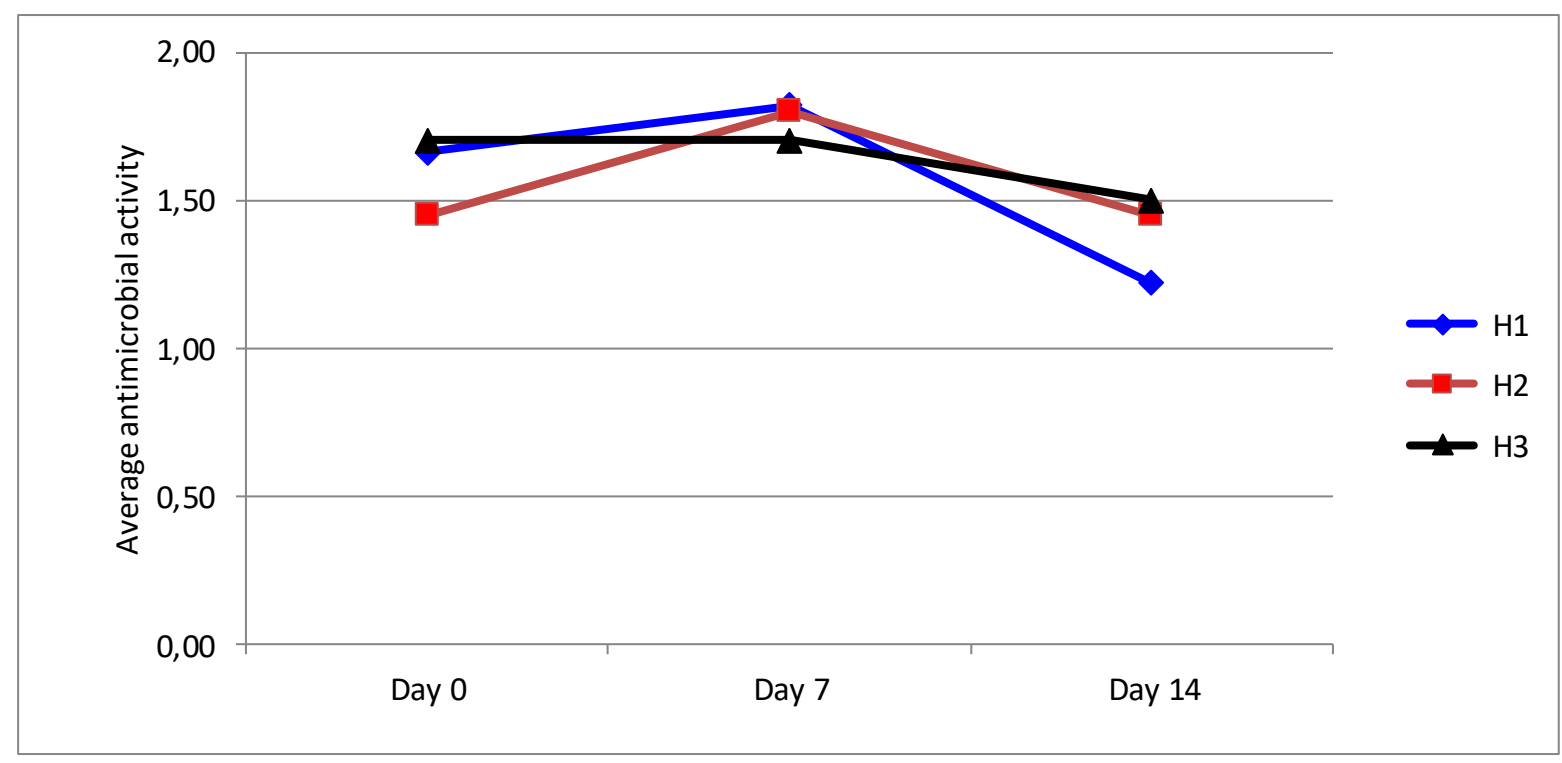

Source: Authors.

Graph 8 - Mean and standard deviation of antimicrobial activity (2.1 x 108 cells inoculated at each time) according to the type of hypochlorite and evaluation time in the clear refrigerator condition.

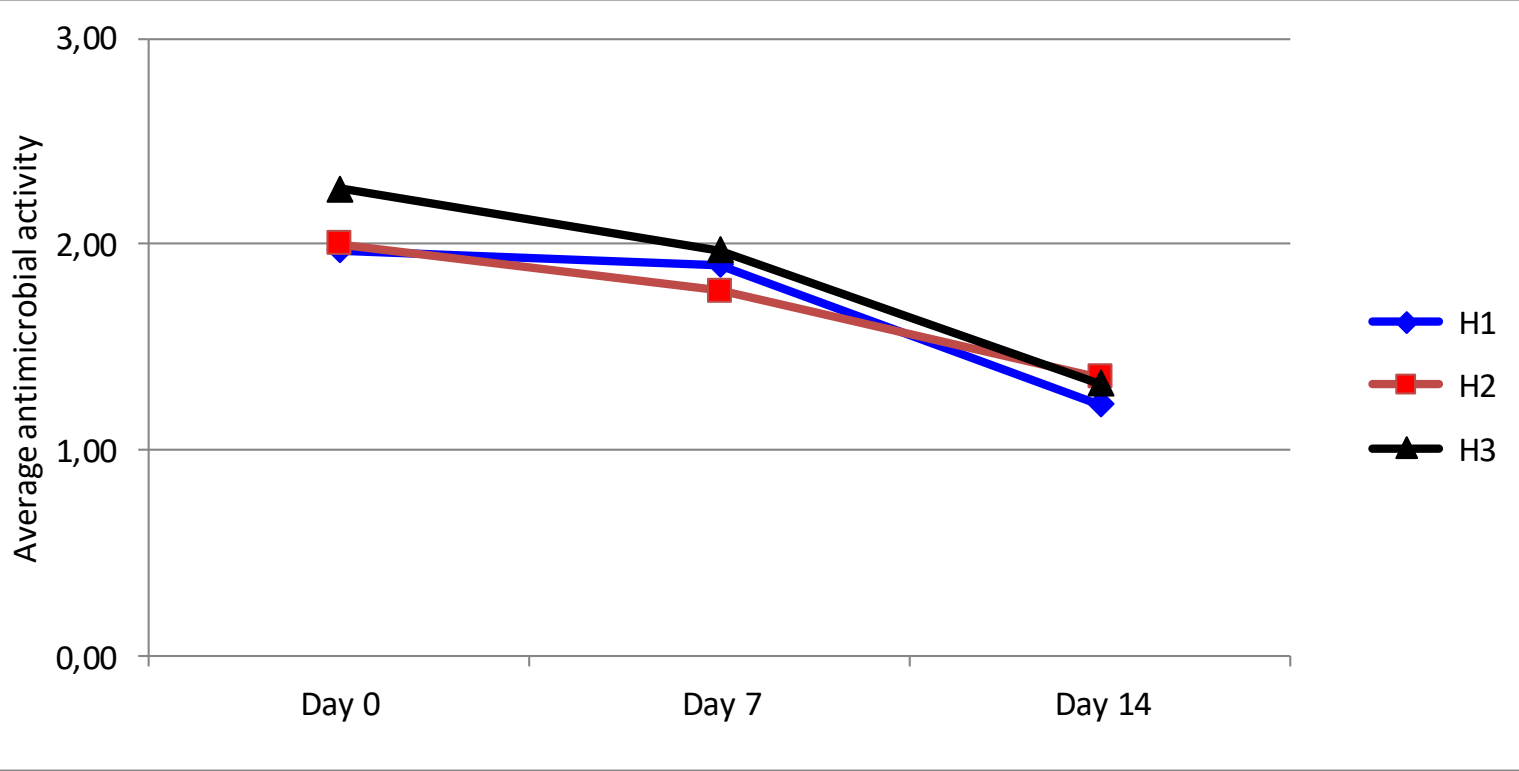

Source: Authors. 
Graph 9 - Mean and standard deviation of antimicrobial activity x (2.1 x 108 cells inoculated at each time) according to the type of hypochlorite and evaluation time in the dark refrigerator condition.

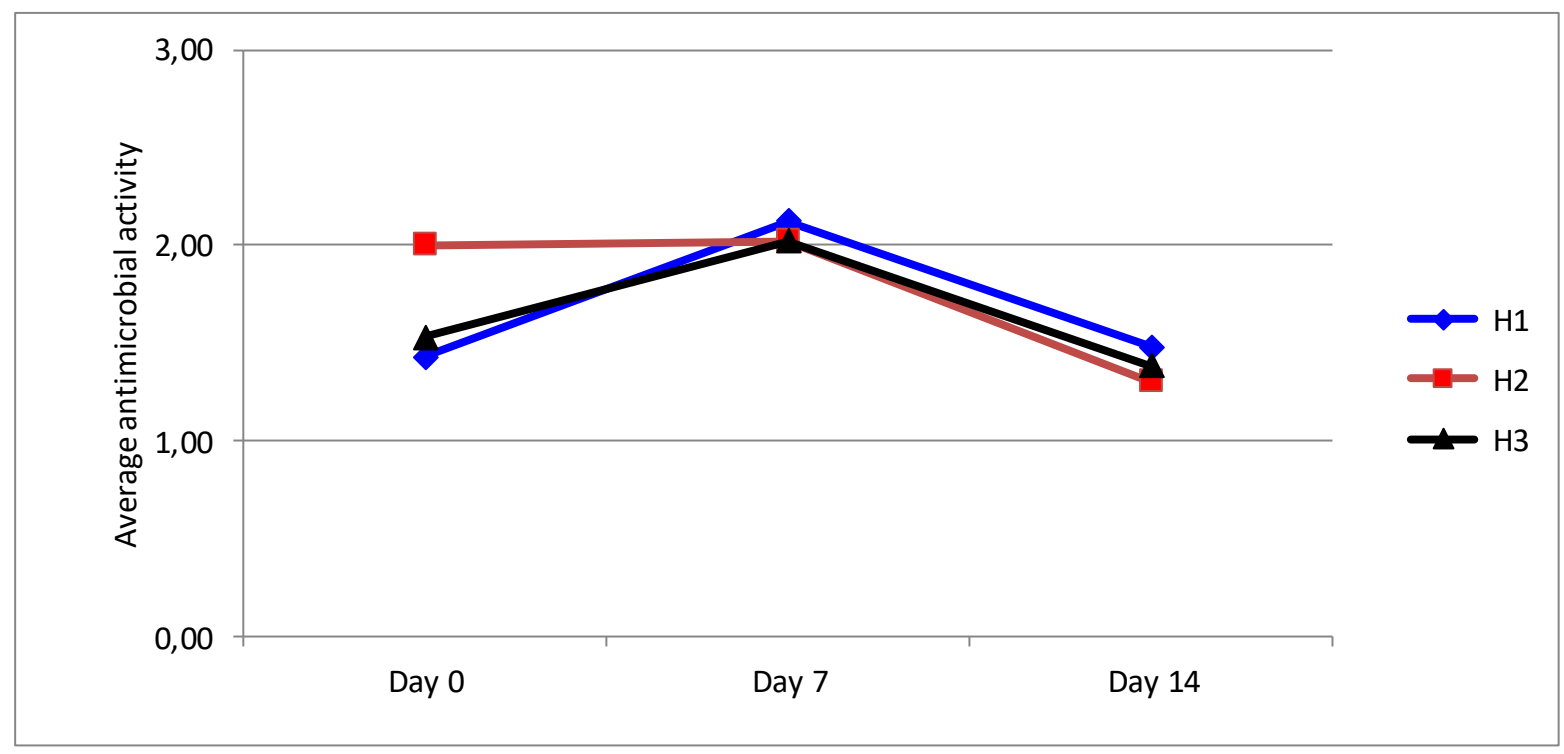

Source: Authors.

Table 2 shows that the mean percent concentration of iodine varied from $1.24 \%$ to $1.54 \%$ in hypochlorites 1 and 2 and varied from $1.59 \%$ to $1.86 \%$ in hypochlorite 3 , being, therefore, higher in hypochlorite 3 than in the other two hypochlorites in each condition and time of evaluation. The values of the standard deviations were not high since these measurements were less than $1 / 3$ of the corresponding means. As can also be seen in Graph 10. 
Table 2 - Mean and standard deviation of the percent concentration of iodometry according to the condition, type of hypochlorite and evaluation time.

\section{Time in days}

Condition

\section{Hypochlorite type Day 0}

Day 7

Day 14

Value of $p$

Average \pm SD Average \pm SD Average \pm SD

\section{Temperature}

Environment with 1

\begin{tabular}{llllll}
\multirow{2}{*}{ Luminosity } & & $1,50 \pm 0,01$ & $1,49 \pm 0,00$ & $1,54 \pm 0,01$ & \\
& 2 & $1,52 \pm 0,02$ & $1,39 \pm 0,01$ & $1,40 \pm 0,00$ & $\mathrm{p}^{(1)}=0,123$ \\
& 3 & $1,84 \pm 0,03$ & $1,59 \pm 0,06$ & $1,80 \pm 0,00$ & $\mathrm{p}^{(1)}=0,095$
\end{tabular}

Value of $p$

$\mathbf{p}^{(2)}=\mathbf{0 , 1 2 3}$

Temperature
Environment
without

Luminosity

3

Value of $p$

$\begin{array}{ll}\text { Temperature } & 1 \\ \text { Refrigerated with } & 2 \\ \text { Luminosity } & 3\end{array}$

Value of $p$

1

$1,49 \pm 0,00$

$1,44 \pm 0,06$

$1,49 \pm 0,00$

$\mathrm{p}^{(1)}=0,368$

2

3

$1,53 \pm 0,00$

$1,50 \pm 0,02$

$1,50 \pm 0,01$

$\mathrm{p}^{(1)}=0,156$

$1,65 \pm 0,08$

$1,70 \pm 0,00$

$1,67 \pm 0,01$

$\mathrm{p}^{(1)}=0,555$

$\mathbf{p}^{(2)}=0,089 \quad \mathbf{p}^{(2)}=0,115 \quad \mathbf{p}^{(2)}=0,123$ $\mathrm{p}^{(1)}=0,123$

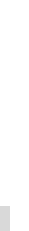


Graph 10 - Mean and standard deviation of Iodometry percent concentration according to condition, type of hypochlorite and evaluation time.

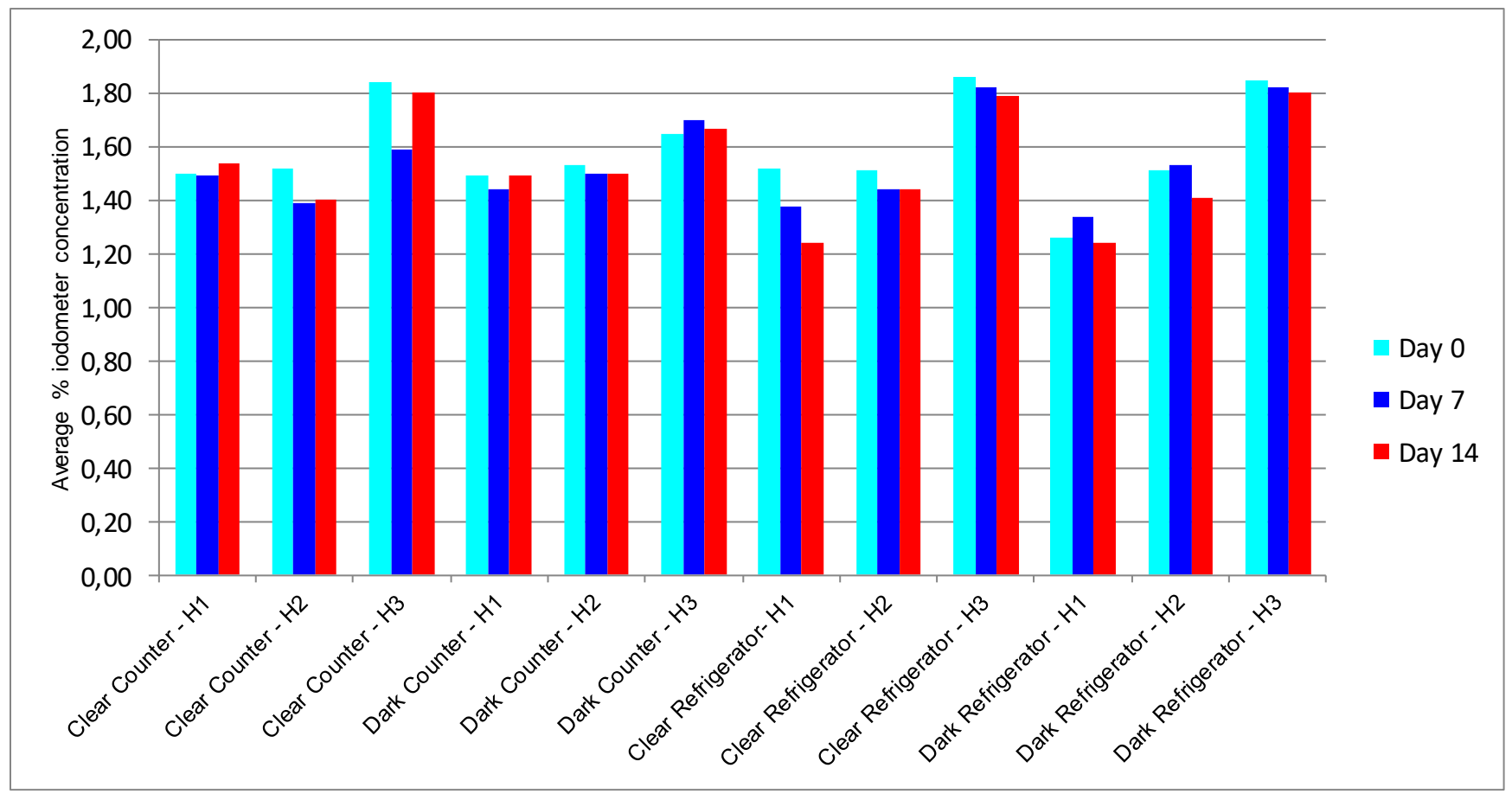

Source: Authors.

No significant differences were recorded between the conditions in any of the three sodium hypochlorite solutions in any of the evaluations $(p>0.05)$ with respect to the percentage concentration of Iodometry, as shown in Table 2. Finally, we recorded the average concentration of all conditions and time intervals of the Sodium Hypochlorite solutions as can be seen in Table 3 and 4.

Table 3 - Average concentration of all conditions of Sodium Hypochlorite solutions in the tested intervals.

\begin{tabular}{|l|l|l|l|}
\hline NaClO Solutions & Day 0 & Day 7 & Day 14 \\
\hline Manipulated & $1,44 \%$ & $1,41 \%$ & $1,37 \%$ \\
\hline Chlorinated Soda & $1,51 \%$ & $1,46 \%$ & $1,43 \%$ \\
\hline Brilux & $1,80 \%$ & $1,73 \%$ & $1,76 \%$ \\
\hline
\end{tabular}

Source: Authors.

Table 4 - Average concentration of all conditions and time intervals of the Sodium Hypochlorite solutions.

\begin{tabular}{|l|l|}
\hline NaClO Solutions & Average Solutions \\
\hline Manipulated & $1,41 \%$ \\
\hline Chlorinated Soda & $1,47 \%$ \\
\hline Brilux & $1,76 \%$ \\
\hline
\end{tabular}

Source: Authors. 


\section{Discussion}

The increased chances of success of endodontic therapy is due to the maintenance of the active chlorine content of sodium hypochlorite solutions, and with that, the efficient disinfection of root canals (Esteves \& Froes, 2013; Ferraz, Falcão, Rego \& Oliveira, 2015).

The choice of sodium hypochlorite at a concentration of $2.5 \%$ for the tests in this research was determined by its effectiveness in dissolving organic material and proven action against microorganisms (Vinhorte, Suzuki, Carvalho, Marques, Júnior, \& Garcia, 2014).

The $\mathrm{pH}$ of these solutions determines the balance of available free chlorine and therefore influences the biological effect (Graça, 2014). Given the results obtained in this experiment, it was verified that despite a small existing increase, all $\mathrm{pH}$ values increased at 14 days of storage, except for the solution of Sodium Hypochlorite 2 (Chlorinated Soda Asfer), in the condition of room temperature without light, because there was a stability since its first use. These results differ from those found by some authors, who observed a decline or constancy of pH over time (Rossi-fedele, Guastalli, Doğramacı, Steier \& De Figueiredo, 2011; Camaões, Freitas, Santiago, Gomes \& Menezes, 2017). In the present study, the pH of the solutions was elevated, ranging from 11 to 13, providing a slower loss of active chlorine content, making the solutions tested more stable, preserving their antimicrobial capacity, and increasing the shelf life of the solution. A pH lower than 9 is not acceptable, as it makes the solution unstable and toxic to biological tissues (Romolu et al., 2015; Prado, Figueiredo, Pires, Corrêa, \& Araújo, 2012; Borin \& Oliveira, 2008).

It is known that when sodium hypochlorite comes into contact with water, it releases sodium and hypochlorite ion as shown in Figure 1:

Figure 1 - reaction of sodium hypochlorite coming into contact with water.

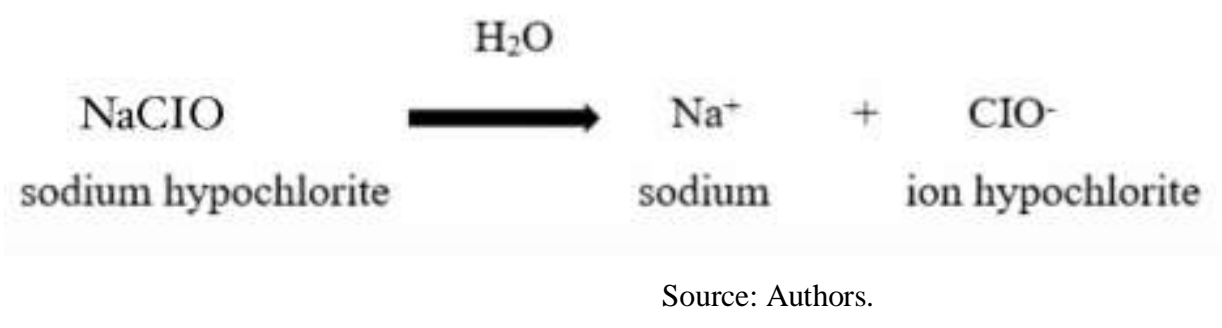

The sodium cation does not hydrolyze because it is a strong cation, while the hypochlorite anion, which is a weak anion, hydrolyzes, i.e., reacts with water forming hypochlorous acid and hydroxyl ion, as shown in the following reaction (Figure 2):

Figure 2 - reaction of hypochlorite ion with water.

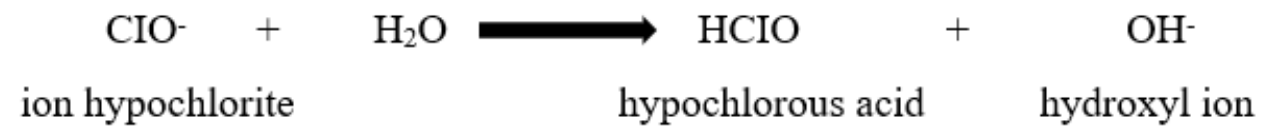

Source: Authors.

The hypochlorous acid undergoes photolysis and releases chlorine, while the hydroxyl ion, which is a strong anion, being released in the hydrolysis reaction when it remains in solution, makes the $\mathrm{pH}$ more basic. In the present stability study, 
all the solutions analyzed lost chlorine over time, however, the hydroxyl ion remained in the solution, which led to an increase in its $\mathrm{pH}$.

The results obtained in this study were favorable for the stability of the sodium hypochlorite solutions analyzed even 7 and 14 days after their first use (Borin, Melo, Becker, Oliveira \& Queiróz, 2006; Borin \& Oliveira, 2008). In the clinic, regarding $\mathrm{pH}$, all tested substances are effective in up to 14 days of use, regardless of the storage mode, i.e., even in packages not protected from light or at room temperature. These results differ from those found by (Borin \& Oliveira 2008; Ludwig et al., 2007) when it was observed that exposure to sunlight and high temperature causes the decomposition of hypochlorous acid, a component that promotes antimicrobial action present in sodium hypochlorite, releasing free chlorine and oxygen, resulting in an almost innocuous solution for endodontic purposes.

In this study, the bacteria used was Enterococcus faecalis because it stands out in secondary endodontic infections, being able to develop both in aerobiosis and anaerobiosis. Present in small proportion in primary infections, being frequently found in endodontically filled canals with signs of chronic apical periodontitis (Nacif \& Alves, 2011; Pinheiro et al., 2018). Studies have shown that this bacterium is associated with cases of failure in endodontic treatments because it has survival, growth, and recovery mechanisms, allowing a small population to survive for up to 12 months without additional nutrients (Nacif \& Alves, 2011). In the antimicrobial activity, all solutions were considered satisfactory in inhibiting the bacteria tested, even with a decrease in the size of the halo over time. This result differs from other studies that reported that absolute control of E. faecalis infection in the root canal system was not possible. (dos Santos, Dall'Magro, Kuhn-Dall'Magro, Corrêa, Fronza, \& Colla, 2012)

The brand that had the largest halo, which is how much the solution is able to inactivate the bacteria, was Brilux. And this result occurred in the condition of refrigerated temperature with luminosity, in the interval of 0 days. The Sodium Hypochlorite solutions with the smallest halo were Brilux and Manipulated. Brilux, in the condition of ambient temperature with luminosity in the interval of 14 days, and Manipulated, in the condition of ambient temperature without luminosity in the interval of 14 days. All the results were statistically significant, except for Brilux in the condition of ambient temperature without luminosity. The best result in the effectiveness of the antimicrobial action of the manipulated solution was in the condition of refrigerated temperature without luminosity in the time interval of 7 days. The Asfer Chlorinated Soda solution, on the other hand, was at room temperature with luminosity in the interval of 0 days. And the Brilux solution was the condition of refrigerated temperature with light in the interval of 0 days.

Regarding the concentration, it was observed that none of the Sodium Hypochlorite solutions was within what was described on the package labels $(2.5 \%)$. However, it was found that there was no statistical difference between the brands, between the storage locations, or the presence of light, but among the three solutions tested, the one that remained closest to what was described on the label was the Brilux brand, even with the differences in light and temperature. And the solution that proved to be less concentrated, regardless of the time interval, was the manipulated sodium hypochlorite, which differs from other studies (Romolu et al., 2015; Camões et al., 2017) that showed no difference between the manipulated and commercially sold, however, there is lack of control among some manufacturers/manipulators as to the actual concentration of active chlorine.

The time intervals were chosen in order to represent that used in clinical settings, whether used by endodontic specialists or clinicians performing endodontic treatment (Camargo et al., 2008; Borin \& Oliveira, 2008).

This means that we need to renew more of these substances in the canal because even with this percentage below expectations, we were able to achieve an effective inhibition of the bacteria tested up to 14 days. However, when this substance comes into contact with the bacteria/organic tissue it will react and then become inert within the canal. Therefore, when we buy a $2.5 \%$ sodium hypochlorite, even recently opened or up to 14 days, it will already have a lower concentration, but it will 
still be effective, but we need, given the complexity of the internal anatomy of the tooth and since we don't know where it is acting, to always renew this substance because there is already a loss in concentration and, consequently, in its action against the microorganism.

It was also observed that there is no need to protect $\mathrm{NaClO}$ from light and heat, because it was found, through the work done, that these conditions do not alter its properties and its antimicrobial capacity.

\section{Conclusion}

The Hydrogenic Potential of the Sodium Hypochlorite solutions tested, in the different storage conditions and in the different time intervals presented ideal values. The $\mathrm{pH}$ remained within a standard range, but increased with the passage of time and the conditions tested.

In the concentration, it was analyzed that there was no statistically relevant difference. However, it was observed that the concentration of the three brands tested does not match what is described on the label, but it was found that among these brands the Brilux brand is the one that remains more concentrated and close to the described value (2.5\%). And the one that was shown to be less concentrated was the manipulated solution.

All tested solutions were effective in terms of antimicrobial activity. However, there was a decline in effectiveness over time and according to the variables tested.

It was concluded that the storage location and exposure to light do not alter the physical-chemical properties of the $2.5 \%$ sodium hypochlorite solution.

It is expected that further studies will be conducted in the development of more stable endodontic irrigants and thus increase their effectiveness in disinfecting the root canal system.

\section{References}

Ávila, L. M., dos Santos, M., Siqueira, E. L., Nicoletti, M. A., \& Bombana, A. C. (2010). Análise das soluções de hipoclorito de sódio utilizadas por endodontistas. RSBO Revista Sul-Brasileira de Odontologia, 7(4), 396-400.

Borin, G., \& de Oliveira, E. P. M. (2008). Análise da estabilidade química da solução de hipoclorito de sódio a 1\% levando-se em consideração o local de armazenamento e a quantidade de solução presente no frasco. RSBO Revista Sul-Brasileira de Odontologia, 5(3), 7-12.

Borin, G., de Melo, T. A. F., Becker, A. N., de Oliveira, E. P. M., \& de Queiróz, M. L. P. (2006). Análise da concentração e do pH de diferentes soluções de hipoclorito de sódio encontradas no mercado. Stomatos, 12(23), 29-34.

Camargo, S. E. A., Blanco, T. M., Lima, R. Y., Rode, S. M., \& Camargo, C. H. R. (2008). Avaliação do pH das soluções de hipoclorito de sódio 1\% e 2, 5\% e digluconato de clorexidina $2 \%$ em função do tempo. Odonto, 16(31), 85-91.

Camões, I. C. G., Freitas, L. F., Santiago, C. N., Gomes, C. C., \& de Menezes, F. V. (2017). Análise da concentração e do ph de diferentes marcas comerciais de hipoclorito de sódio. Revista de Odontologia da Universidade Cidade de São Paulo, 24(1), 15-18.

Camps, J., Pommel, L., Aubut, V., Verhille, B., Satoshi, F., Lascola, B., \& About, I. (2009). Shelf life, dissolving action, and antibacterial activity of a neutralized $2.5 \%$ sodium hypochlorite solution. Oral surgery, oral medicine, oral pathology, oral radiology, and endodontology, $108(2)$, e66-e 73.

dos Santos, T. L., Dall'Magro, E., Kuhn-Dall’Magro, A., Corrêa, B., Fronza, B. M., \& Colla, F. (2012). Ação antimicrobiana do hipoclorito de sódio a 2, 5\% e clorexidina gel $2 \%$ em raízes contaminadas com Enterococcus faecalis. Revista da Faculdade de Odontologia-UPF, 17(2).

Dioguardi, M., Di Gioia, G., Illuzzi, G., Laneve, E., Cocco, A., \& Troiano, G. (2018). Endodontic irrigants: Different methods to improve efficacy and related problems. European journal of dentistry, 12(3), 459.

Esteves, D. L. S., \& Froes, J. A. V. (2013). Soluções Irrigadoras em Endodontia-Revisão de Literatura. Arquivo Brasileiro de Odontologia, 9(2), 48-53.

Estrela, C., Estrela, C. R. A., Decurcio, D. A., Hollanda, A. C. B., \& Silva, J. A. (2007). Antimicrobial efficacy of ozonated water, gaseous ozone, sodium hypochlorite and chlorhexidine in infected human root canals. International endodontic journal, 40(2), 85-93.

Fabro, R. M. N., Britto, M. L. B., \& Nabeshima, C. K. (2010). Comparação de diferentes concentrações de hipoclorito de só dio e soro fisiológico utilizados como soluções irrigadoras. Odontologia Clínico-Científica (Online), 9(4), 365-368.

Ferraz, M. Â. A. L., Falcão, C. A. M., Rego, L. M., \& de Carvalho Oliveira, F. (2015). O teor de cloro ativo em soluções de hipoclorito de sódio. Revista Interdisciplinar, 8(2), 20-24. 
Ferreira, G. C. (2016). Avaliação da interação química do hipoclorito de cálcio associado ao EDTA e à clorexidina estudo preliminar.

Graça, B. P. (2014). O Hipoclorito de sódio em Endodontia (Doctoral dissertation, [sn]).

Lin, J., Shen, Y., \& Haapasalo, M. (2013). A comparative study of biofilm removal with hand, rotary nickel-titanium, and self-adjusting file instrumentation using a novel in vitro biofilm model. Journal of endodontics, 39(5), 658-663.

Lopes, R. M. V., Marins, F. C., Belladonna, F. G., Souza, E. M., De-Deus, G., Lopes, R. T., \& Silva, E. J. N. L. (2018). Untouched canal areas and debris accumulation after root canal preparation with rotary and adaptive systems. Australian Endodontic Journal, 44(3), $260-266$.

Ludwig, A., Hoffmeister, M. K., Irala, L. E. D., Salles, A. A., Limongi, O., \& Soares, R. G. (2007). Análise da concentração de cloro ativo e pH em amostras de hipoclorito de sódio $1 \%$. RSBO (Impr.), 29-36.

Nacif, M. C. A. M., \& Alves, F. R. F. (2011). Enterococcus faecalis na Endodontia: um desafio ao sucesso. Revista brasileira de odontologia, 67(2), 209.

Neris, C. W. D., Arruda, M. F., Duque, T. M., Neris, C. K. D., \& Galindo, J. K. S. N. (2015). O hipoclorito de sódio e seus conceitos de aplicabilidade na endodontia. REVISTA UNINGÁ REVIEW, 24(3).

Paixao, L. C., \& Maltos, K. M. (2016). Hipoclorito de sódio versus clorexidina na irrigação endodôntica. Revista do CROMG, 17(1).

Pereira, A. S., Shitsuka, D. M., Parreira, F. J., \& Shitsuka, R. (2018). Metodologia da pesquisa científica. UFSM. https://repositorio. ufsm. br/bitstream/handle/1/15824/Lic_Computacao_Metodologia-Pesquisa-Cientifica.pdf.

Pinheiro, S. L., da Silva, C. C., da Silva, L. A., Cicotti, M. P., da Silveira Bueno, C. E., Fontana, C. E., ... \& de Campos, F. U. (2018). Antimicrobial efficacy of $2.5 \%$ sodium hypochlorite, $2 \%$ chlorhexidine, and ozonated water as irrigants in mesiobuccal root canals with severe curvature of mandibular molars. European journal of dentistry, 12(1), 94.

Pitome, A. W., Cruz, A. T. G., Heck, A. R., Faria, M. I. A., \& Aragão, E. M. D. (2015). Avaliação da capacidade de dissolução de tecido pulpar bovino pelo hipoclorito de sódio em diferentes concentrações. Revista de Odontologia da UNESP, 44(6), 351-354.

Plotino, G., Cortese, T., Grande, N. M., Leonardi, D. P., Di Giorgio, G., Testarelli, L., \& Gambarini, G. (2016). New technologies to improve root canal disinfection. Brazilian dental journal, 27(1), 3-8.

Prado, M., Figueiredo, J. P. O., Pires, D. C. A., Corrêa, A. C. P., \& Araújo, M. C. P. (2012). Efeitos da temperatura e do tempo de armazenamento na estabilidade química de soluções de hipoclorito de sódio. Rev Odontol UNESP, 41(4), 242-46.

Romolu, P. L., Britto, M. L. B., Machado, M. E. D. L., \& Nabeshima, C. K. (2015). Comparação do teor de cloro ativo e pH do hipoclorito de sódio 0, 5\% fabricado e manipulado. Full dent. sci, 7(25), 130-134.

Rossi-Fedele, G., Guastalli, A. R., Doğramac1, E. J., Steier, L., \& De Figueiredo, J. A. P. (2011). Influence of pH changes on chlorine-containing endodontic irrigating solutions. International endodontic journal, 44(9), 792-799.

Versiani, M. A., De-Deus, G., Vera, J., Souza, E., Steier, L., Pécora, J. D., \& Sousa-Neto, M. D. (2015). 3D mapping of the irrigated areas of the root canal space using micro-computed tomography. Clinical oral investigations, 19(4), 859-866.

Vinhorte, M. C., Suzuki, E. H., de Carvalho, M. S., Marques, A. A. F., Júnior, E. C. S., \& Garcia, L. D. F. R. (2014). Effect of passive ultrasonic agitation during final irrigation on cleaning capacity of hybrid instrumentation. Restorative dentistry \& endodontics, $39(2), 104$.

Yoo, Y. J., Perinpanayagam, H., Oh, S., Kim, A. R., Han, S. H., \& Kum, K. Y. (2019). Endodontic biofilms: contemporary and future treatment options. Restorative dentistry \& endodontics, 44(1). 